\title{
Mengisahkan Ziarah Eksodus Melalui Eksterior Bangunan Gereja
}

\author{
Rasid Rachman \\ Sekolah Tinggi Filsafat Teologi Jakarta \\ rasidrachman@yahoo.co.id \\ D01: https://doi.org/10.34307/b.v4i2.273
}

\begin{abstract}
The exterior of Church building is a clearest face of the community of its members, because it is openly showed by anybody. It is not only an evidence of the very art and historical heritage, but also a content of theological narrative and re-narrative of Church role in the world. This writing will show that there is a theological narrative behind the Church building. In this writting, that theological narrative is limited on the story of the journey and the sojourn of the Israel people in the wilderness to the promised land. From the exodus narrative, I renarrate the role of the Church in the context where it lives. This writing used the theory of bottom with three elements, namely: concept, categori, and proposition. The early consept is exodus narrative according to the Bible. Catching the category, this exodus concept will be anriched by the blended with the narrative of some Church buildings in Indonesia, theology of the Old Testament and liturgy, the antropology of cultural, and the philosophy of architecture. The result of this research is renarrative of the living Church buildings. The proposition is an offer on an interrelation between Biblical narrative, historical roll of the Church building, and the renarrative or the storytelling renewal, with the present of Church mission.
\end{abstract}

Keywords: exodus, holy mountain, tent, journey, sojourn

\begin{abstract}
Abstrak: Eksterior bangunan gereja adalah wajah paling jelas persekutuan anggotanya, sebab terlihat secara terbuka oleh siapa pun. Ia bukan hanya bukti mahakarya seni arsitektur dan peninggalan sejarah, tetapi juga berisi narasi teologis dan merenarasikan peran gereja di dunia. Tulisan ini ingin memperlihatkan bahwa ada narasi teologi di balik eksterior bangunan gereja. Dalam tulisan ini, narasi teologi tersebut dibatasi pada kisah perjalanan dan persinggahan umat Israel di padang gurun menuju tanah perjanjian. Dari narasi eksodus tersebut, saya merenarasikan peran gereja di dalam konteksnya.Tulisan ini menggunakan teori dari bawah dengan tiga unsur, yaitu: konsep, kategori, dan proposisi. Konsep awal adalah narasi eksodus sebagaimana kesaksian Alkitab. Untuk mencapai kategori, konsep eksodus ini akan diperkaya dengan memadukan narasi beberapa bangunan gereja di Indonesia, teologi Perjanjian Lama dan liturgi, antropologi budaya, dan filsafat arsitektur. Hasil penelitian adalah renarasi bangunan gereja yang hidup. Proposisi berupa tawaran akan hubungan-hubungan antara narasi Alkitab, guliran historis bangunan gereja berdiri, dan renarasi atau pembaruan penceritaan, dengan misi gereja kini.
\end{abstract}

Kata Kunci: eksodus, gunung suci, kemah, perjalanan, persinggahan. 


\section{Pendahuluan}

Aksioma: "Gereja bukanlah gedungnya," dalam paparan ini adalah sebuah pemeo. Alasannya, sekalipun inti gereja adalah umat, namun gedung gereja adalah hal penting berikutnya setelah membicarakan umat. Membicarakan gereja, setelah bersemuka ${ }^{1}$ dengan umat, diikuti dengan pertanyaan: "Di manakah gerejamu?" Setidaknya, seseorang perlu mendapat informasi tentang lokasi umat beribadah, baik berupa tempat, nama, maupun bangunan gereja. Lagipula tidak sedikit pihak yang mengorbankan banyak hal untuk sebuah bangunan gereja. Bagaimana pun, bangunan gereja adalah sebuah nilai maha karya dan warisan sejarah kasat mata dalam kekristenan dan budaya dunia.

Paparan berikut: Eksterior Bangunan Gereja: Mengisahkan Ziarah Eksodus, adalah tentang melihat tata letak bangunan gereja dalam bingkai perjalanan ke tanah perjanjian dan persinggahan di padang pasir. Beberapa bangunan gereja, dalam perspektif saya, mengimajinasikan kisah eksodus umat Israel. Eksterior adalah bagian paling kasat mata, bahkan menonjol, sebuah bangunan.

Eksterior gereja, pada satu sisi mengingatkan keterbatasan gereja sebagai ruang mikro yang terikat pada lokasi, tempat, posisi ( (ómo $^{2}$ ) dan waktu, masa, dan zaman. Pada lain sisi, ini yang hendak diangkat melalui paparan berikut, bangunan gereja mengimajinasikan kisah dan menarasikan karya Allah yang nir-batas tempat dan waktu. Laksana manusia, tubuhnya menyimpan pengalaman. Berbeda dengan slogan finitum non est capax infiniti (yang terbatas tidak dapat berisi yang tak terbatas), ${ }^{3}$ keterbatasan bangunan gereja berpotensi menyampaikan narasi pengalaman bersama Allah dan karya-Nya yang nir-batas. ${ }^{4}$

Bangunan gereja, berdasarkan Masao Takenaka, bukan hanya menarasikan karya Allah yang nir-batas (Kej. 1:1; 2:4 "langit dan bumi"). Bangunan gereja juga merenarasikan tubuh Kristus di dunia, yakni gereja (bnd. Kej. 1:26; 2:8 penciptaan manusia di taman), menurut konteks ruang terbatas dan budaya nir-batas. ${ }^{5}$ Paparan berikut kami batasi pada perjalanan umat Israel ke tanah perjanjian sebagai narasi eksterior bangunan gereja.

1 Kamus Besar Bahasa Indonesia Versi Daring, s.v "bersemuka": 1) berhadapan-hadapan muka; 2) bertemu muka (dengan); berhadapan langsung (dengan); bertatap muka (dengan). https://www.kbbi.web.id/.

2 Barclay M Newman, "Greek-English Dictionary of the New Testament" (Stuttgart: Deutsche

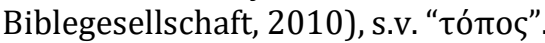

3 Bnd.Carlos M N Eire, War Against the Idols: The Reformation of Worship from Erasmus to Calvin (Cambridge: Cambridge University Press, 1986), 197-198.

4 Ibid, 197.

5 Bnd. Masao Takenaka, The Place Where God Dwells (Hongkong: CCA dan Asian Christian Art Association, 1995), 14-15. 
Bangunan gereja cenderung statis, namun teologi dinamis. Yang dimaksud


bertenaga. ${ }^{6}$ Teologi, yakni percakapan tentang Allah, adalah dinamis, karena ia hidup dan bergerak. Berbeda dengan narasi penciptaan alam semesta, manusia, penugasan misi kepada manusia, dan Allah berhenti pada hari ketujuh (Kej. 1 - 2:3). Narasi eksodus adalah narasi Allah mendengar jeritan umat, mengutus Musa (Kel. 3:7-10), dan terus terlibat aktif di sepanjang perjalanan di padang pasir, memasuki tanah Kanaan, dan sepanjang kehidupan umat-Nya.

Perjalanan umat Israel ke tanah perjanjian selama 40 tahun (Bil. 14:32-35) menyimbolkan ziarah kehidupan. Pasang-surut kehidupan yang mewarnai perjalanan itu menjadi pengingat umat Allah akan pelajaran kesetiaan. Dalam pergulatan dengan dunia sekitar, teologi tertantang untuk menarasikan bangunan gereja secara baru.

Pada satu sisi, bangunan gereja pada dirinya mengandung narasi teologis. Yang juga bernarasi adalah bangunan gereja, meminjam istilah Y.B. Mangunwijaya, yang berarsitektur eclecticismus (campur aduk apa saja tanpa prinsip) dan catalogue of the past (menjiplak). ${ }^{7}$ Narasi teologis tersebut bukan tercipta oleh karena aturan ayat-ayat tertentu atau hukum teknis sipil belaka. Sebaliknya, Kitab Suci dan perguliran (suatu) gereja menceritakan karya Allah menurut penghayatan iman umat di atas pijakan bangunan gereja berdiri. Takenaka menulis bahwa bangunan gereja merupakan warisan yang menginspirasi kreativitas di dalam konteks ruang dan waktu. ${ }^{8}$ Cerita tersebut tertuang melalui penyajian bangunan gereja. Oleh karena itu, melihat bangunan gereja dalam persektif teologis bukan hanya mengutamakan estetika dan fungsional, tetapi juga narasi yang digulirkannya.

Sebelum ini telah ada beberapa tulisan teologi tentang bangunan gereja tentang teknis arsitektur, model bangunan, lokalitas model, dan cerminan denominasi gereja. Di antara tulisan tersebut adalah Robert Boehlke, Sejarah Pendidikan Agama Kristen (1990) tentang model bangunan sebagai metode pendidikan. Masao Takenaka, The Place Where God Dwells (1995) tentang model-model Gereja di Asia, termasuk Indonesia. Gereja tersebut antara lain: St Paulus di Kerten-Solo, GMIT Kalabahi, Alor-NTT, dan beberapa GKPB di Bali. 9 Tulisan terbaru adalah hasil Studi Institut PERSETIA "Arsitektur dan Liturgi Gereja“ di Suka Meriah, Karo-Sumatera Utara 22 - 25 April 2014, namun tidak diterbitkan. Adolf Heuken menulis Gereja-gereja Tua di Jakarta (2003), berisi kajian

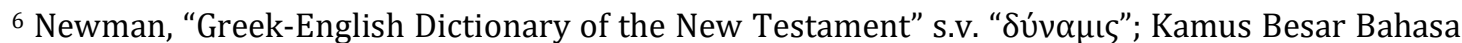
Indonesia Versi Daring, s.v. "dinamis": penuh semangat dan tenaga sehingga cepat bergerak dan mudah menyesuaikan diri dengan keadaan; Eire, War Against the Idols: The Reformation of Worship from Erasmus to Calvin, 199.

7 Y B Mangunwijaya, Wastu Citra: Pengantar Ke Ilmu Budaya Bentuk Arsitektur Sendi-Sendi Filsafatnya Beserta Contoh-Contoh Praktis (Jakarta: Gramedia Pustaka Utama, 1995), 140-143.

${ }^{8}$ Takenaka, The Place Where God Dwells, 9.

${ }^{9}$ Ibid, 98-107. 
bangunan dengan narasi historis. Paparan Heuken tampak mendekati paparan saya ini. Semua tulisan tersebut berupa analisis kontekstualisasi dan sejarah. ${ }^{10}$ Namun, paparan saya berikut ini tidak kembali menarasikan bangunan gereja sebagai sajian data sejarah atau analisis kontekstualisasi.

\section{Metode penelitian}

Paparan saya akan berangkat dari eksterior bangunan gereja yang telah ada, kemudian menarasikan ulang. Narasi ulang atau renarasi, bagi saya adalah penting. Sebab, bangunan gereja yang telah berdiri mengimajinasikan perjalanan umat Allah, terutama ke tanah perjanjian atau eksodus yang berlanjut dalam sejarah. Contoh eksterior gereja yang saya paparkan terbatas di Indonesia. Eksterior gereja adalah warisan hidup dan monumen kasat mata yang merenarasikan karya Allah di Indonesia melalui komunitas beriman. Besar kemungkinan, paparan ini tidak tersaji oleh para pembangun semula. Karena itulah, paparan ini menyajikan narasi ulang dan baru atas bangunan gereja.

Sebagai dasar pemaparan untuk perspektif yang lebih luas, saya akan menggunakan narasi umum perihal bangunan gereja sebagai rumah umat berliturgi. Tulisan Heinz Frick, Arsitektur dan Lingkungan (1994), dan tulisan Y.B. Mangunwijaya, Wastu Citra (1995), merupakan pengaya paparan ini. Kedua tulisan inspiratif tersebut, bagi saya, menyajikan narasi bagi gereja. Saya menyandingkan kedua sumber tersebut bersama sumber-sumber teologi dan budaya untuk membangun narasi. Narasi adalah hal penting dalam berliturgi, karena ia membentuk dan menghidupkan selebrasi. ${ }^{11}$ Narasi adalah fondasi agama dan ritus, demikian pula narasi bagi bangunan gereja sebagai "rumah" ritus kasat mata.

\section{Hasil dan Pembahasan}

\section{Perjalanan dan persinggahan ke tanah perjanjian sebagai narasi eksterior gereja}

Keluarnya umat Israel dari Mesir menuju tanah perjanjian, diperkirakan antara 1628 SM (tahap pertama) dan 1450 SM (tahap kedua), ${ }^{12}$ merupakan cerita agung pembentukan iman Israel. Cerita besar eksodus sejumlah besar umat itu terus menerus diulangi oleh para bapak dan ibu leluhur Israel dan para penulis Alkitab. Selain kitab Keluaran, kisah tersebut juga terdapat dalam kitab Bilangan, Ulangan, Yosua, Mazmur, dan Ibrani. Cerita besar itu menjadi narasi umat Israel yang dipersaksikan melalui hari-hari raya Paska

\footnotetext{
10 Ibid, 10. mengutip D.T. Niles perihal tantangan gereja di Asia, yaitu: sinkretisme, ghetoisme, dan lebih unggul daripada yang lain

11 Rasid Rachman, "Narasi Membangun Selebrasi: Gulir Ritual Kekristenan Awal," Indonesian Journal of Theology 8, no. 2 (2020): 131-156, https://doi.org/10.46567/ijt.v8i2.179.

12 Barbara J Sivertsen, The Parting of the Sea: How Volcanoes, Earthquakes, and Plagues Shaped the Story of Exodus (Princeton dan Oxford: Princeton University Press, 2009), 2. mengabaikan dua versi berbeda, bnd. Sivertsen, 42-43, dan 142.
} 
dan Pondok Daun. ${ }^{13}$ Cerita itu juga besar bagi arkeolog dan sejarawan. Barbara Sivertsen memaparkan hasil ekskavasi sekitar delta Nil untuk pembuktian akibat letusan gunung Minoan di Santorini-Yunani sekitar 1628 SM. Letusan terbesar kedua setelah Tambora-Sumbawa (April 1815 M) dalam 4000 ribu tahun tersebut ${ }^{14}$ mengakibatkan bencana ${ }^{15}$ yang dikisahkan dalam sepuluh tulah di Mesir (Kel. 7:14 12:42). ${ }^{16}$ Namun bagi saya, cerita besar itu juga direnarasikan melalui eksterior bangunan gereja.

Selain penyeberangan teberau dan sungai, gunung Tuhan adalah narasi besar


geografis merupakan midpoint antara Mesir dan Kanaan, namun Thomas Dozeman

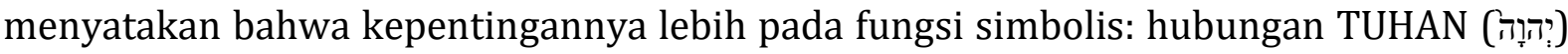
dengan umat-Nya. ${ }^{17}$ Baik TUHAN maupun umat berdiam di tempat masing-masing.


keberadaan TUHAN bersama umat (Kel. 19:3, 20, 25). Peran Musa tidak tampil pada kisah sejajar dalam paparan Deuteronomist dengan tradisi Horeb (Ul. 4:10, 15; 5:2), karena TUHAN langsung berbicara kepada Israel. ${ }^{18}$ Maka, gunung Allah, baik Sinai maupun Horeb, bukan semata soal geografis suatu objek tempat dekat atau jauh, atau Musa sebagai perantara atau bukan, tetapi juga simbolisme sebagai narasi kudus (sacred memory). ${ }^{19}$ Narasi itulah yang terus dihidupkan dalam guliran masa.

Narasi padang pasir tidak hanya perjalanan, tetapi juga persinggahan. Alkitab (Bil. 33:5-49; bnd. Kel. 19:2) mempersaksikan beberapa persinggahan atau perhentian umat Israel. Dalam perikop tersebut, jumlah Israel berjalan ("Mereka berangkat [וספע] dari ...,") ditulis sebanyak jumlah Israel berhenti (“... , lalu berkemah [חִָ $]^{20}$ di ..."). Hanya, Sivertsen menulis bahwa jalur perjalanan Israel adalah kota kecil, kampung, dan desa. Baik tepi laut dan sungai dengan kapal maupun daratan dan perbukitan dengan keledai, merupakan jalur perdagangan barang dan kebutuhan hidup. Beberapa kota, menurut

13 Bnd. Thomas B Dozeman, God on the Mountain: A Study of Redaction, Theology and Canon in Exodus 19-24 (Atlanta: Scholars Press, 1989), 6-7.

14 Sivertsen, The Parting of the Sea: How Volcanoes, Earthquakes, and Plagues Shaped the Story of Exodus, 24-25, berdasarkan Volcanic Explosivity Index 7 (V.E.I.).

15 Ibid, 25-26. $\mathrm{BO}_{0}$ : gempa dan hujan abu beberapa pekan atau bulan sebelum letusan; $\mathrm{BO}_{1}$ : fase erupsi plinian; $\mathrm{BO}_{2}$ : fase kedua, interaksi air laut dengan magma; $\mathrm{BO}_{3}$ : fase ketiga, air laut bercampur dengan magma; $\mathrm{BO}_{4}$ : (tidak semua mencapai) fase akhir, menyebabkan tsunami, kaldera, atau palung.

16 Ibid, 38-42.

17 Dozeman, God on the Mountain: A Study of Redaction, Theology and Canon in Exodus 19-24, 1314, 68-69, berbeda dengan har sînay (gunung Sinai), Horeb tidak disebut har hôrēb (gunung Horeb); LAI, Alkitab Edisi Studi (Jakarta: Lembaga Alkitab Indonesia, 2012), 2086 (Peta Mesir dan Sinai, 1400 - 1200 $\mathrm{SM})$. Exodus, 67.

18 Ibid, 67-68.

${ }^{19}$ Sivertsen, The Parting of the Sea: How Volcanoes, Earthquakes, and Plagues Shaped the Story of

20 D.L. Baker and A.A. Sitompul, "Kamus Singkat Ibrani - Indonesia” (Jakarta: BPK Gunung Mulia,

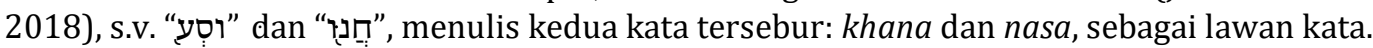


informasi Sivertsen, adalah pusat industri emas dan gading. ${ }^{21}$ Artinya, selain para penggembala, jalur perjalanan dan persinggahan Israel adalah jalur hidup (bnd. Kej. 37:25-28 Yusuf dijual kepada kafilah Ismael atau saudagar Midian yang berjalan dari Gilead ke Mesir) sejak lama. Persinggahan Israel umumnya berada di tepi air atau di desa. Di lokasi itulah Israel mendapat kekuatan baru untuk meneruskan perjalanan ziarah (bnd. 1Raj. 17:2-6 Elia mendapat kiriman makanan di tepi sungai Kerit untuk melanjutkan tugasnya; 1Raj. 19:5-8 Elia mendapat kekuatan setelah "persinggahan" di padang pasir menuju gunung Horeb). Persinggahan adalah pasangan sejati perjalanan.

Alkitab tidak menuliskan lama persinggahan Israel di Sukot, Etam, Pi-Hahirot, Migdol, Elim, Tarah, Mitka, Bene-Yaakann, dan seterusnya hingga tepi sungai Yordan. Namun Sivertsen menghitung bahwa seluruh perjalanan Israel sejak meninggalkan Rameses wilayah Gosyen-Mesir hingga sebelum memasuki Yerikho (1628 - 1550 SM) adalah 78 tahun. Jangka waktu tersebut adalah antara tiga dan empat generasi masa itu. ${ }^{22}$ Ada empat puluh dua tempat persinggahan berdasarkan Bilangan 33:5-49 setelah Rameses. Dalam 28.470 hari perjalanan, waktu yang digunakan untuk berjalan dan tiba di satu tempat singgah adalah rata-rata 677 - 678 hari atau satu tahun sepuluh bulan. Menilik jangka waktu tersebut, alih-alih pengungsi, umat Israel di padang gurun adalah kaum habiru, apiru, atau syasu, yakni kaum nomad, pengembara, atau pengelana tanpa tujuan dan tempat tinggal. ${ }^{23}$ Selama hidup sebagai kaum nomad, para penulis kisah padang gurun membangun narasi gunung Tuhan, perkemahan di tepi air, dan tugu peringatan. Hal-hal tersebut dijumpai secara imajinatif, baik langsung maupun tak langsung, sebagai perjalanan umat Israel menuju tanah perjanjian.

Kisah perjalanan Israel sendiri tidak menetapkan tempat-tempat tertentu sebagai

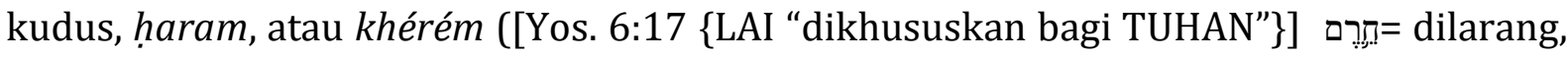
disakralkan, khusus untuk dihancurkan), ${ }^{24}$ kecuali gunung Sinai atau Horeb (Kel. 3:5; 19:12 "memasang batas"; Bil. 18:22). Beberapa bentuk bangunan-luar gereja merupakan rekaman narasi eksodus. Teofani di bukit atau gunung, menara, tepi air, kemah, dan gunung batu merupakan narasi padang gurun. Berdasarkan Roland de Vaux, lokasi

${ }^{21}$ Sivertsen, The Parting of the Sea: How Volcanoes, Earthquakes, and Plagues Shaped the Story of Exodus; Lembaga Alkitab Indonesia, Alkitab Edisi Studi (Jakarta: Lembaga Alkitab Indonesia, 2012), 275. Catatan dan 2086: peta.

22 Sivertsen, The Parting of the Sea: How Volcanoes, Earthquakes, and Plagues Shaped the Story of Exodus, 12 (peta), dan 72-73, bnd. 124 dan 143 (perkampungan ibrani di Mesir); Lembaga Alkitab Indonesia, Alkitab Edisi Studi, 345, "Bangsa Israel sedang bersiap untuk mengakhiri pengembaraan selama 40 tahun di padang gurun".

23 Sivertsen, The Parting of the Sea: How Volcanoes, Earthquakes, and Plagues Shaped the Story of Exodus, 117-118; Kamus Besar Bahasa Indonesia Versi Daring," s.v. "kelana", "nomad", "pengembara".

24 William Osburn, "A Hebrew and English Lexicon to the Old" (Grand Rapids: Zondervan

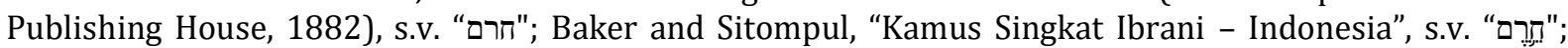
Roland De Vaux Roland, Ancient Israel: Its Life and Institutions, terj. John McHugh (New York: McGraw-Hill Book Company, Inc, 1961), 275. 
teofani kemudian ditetapkan sebagai tempat berbatas yang merupakan larangan bagi kebanyakan orang melampauinya. 25

Pada satu sisi, menurut Cornelis van de Ven, bangunan gereja merupakan seni pembentukan ide atau narasi (ruang abstrak). Oleh karena itu, bangunan konkret mengandung baik materi berwujud maupun materi tak berwujud. ${ }^{26}$ Pada lain sisi, bangunan gereja melahirkan narasi baru seturut guliran zaman, yakni renarasi. Renarasi ini seyogianya sejalan dengan kandungan materi yang telah lebih dahulu ada pada bangunan, sehingga ia memperkaya gereja sebagai bangunan hidup.

\section{Bukit atau gunung}

Ketinggian adalah posisi bagus untuk sebuah bangunan. Y.B. Mangunwijaya menambahkan bahwa posisi rendah dihubungkan dengan realita yang kurang baik, berbahaya, membawa penyakit, atau bandingkan penyebutan kaum bawahan dan orang rendahan. ${ }^{27}$ Maka, mendirikan tempat kudus di tempat tinggi. Ada dua citra-dasar kehidupan, yaitu: 1) gunung dan sila, dan 2) tiang atau tugu. ${ }^{28}$ Citra-dasar kedua akan menjadi pemaparan berikut. Citra-dasar pertama, "gereja gunung". Keindahan dan kemegahan gereja akan bertambah jika berada di atas gunung, baik gunung sejati maupun artifisial. GKJ Katelklawu-Pengalusan, Purbalingga-Jawa Tengah dan GKP Cigugur-Jawa.



Barat, adalah contoh bangunan gereja di atas ketinggian alami. Beberapa bangunan gereja di dataran tinggi, semisal: Tana Toraja dan Sumatera Utara, terletak di atas bukit.

25 De Vaux, Ancient Israel: Its Life and Institutions, 276-277.

26 Bnd. Cornelis Van de Ven, Ruang Dalam Arsitektur: Evolusi Dari Sebuah Gagasan Baru Dalam Teori Dan Sejarah Gerakan-Gerakan Modern, terj. Imam Djokomono dan Prihminto Wio (Jakarta: Gramedia Pustaka Utama, 1991), 95-96.

27 Mangunwijaya, Wastu Citra: Pengantar Ke Ilmu Budaya Bentuk Arsitektur Sendi-Sendi Filsafatnya Beserta Contoh-Contoh Praktis, 96-97; Kamus Besar Bahasa Indonesia Versi Daring, s.v. "bawahan" (diakses 27 April 2021).

28 Mangunwijaya, Wastu Citra: Pengantar Ke Ilmu Budaya Bentuk Arsitektur Sendi-Sendi Filsafatnya Beserta Contoh-Contoh Praktis, 97. 
Penginjil Matius menganalogikan kota di atas gunung pada dirinya memiliki "daya tarik", sehingga tidak mungkin tersembunyi (Mat. 5:13).

Gereja di atas "bukit" terlihat jelas, salah satu dari banyak contoh sama yang tersebar di segala penjuru Nusantara, adalah GPIB Immanuel-Jakarta, rancangan J.H. Horst dan diresmikan pada 1839. Memandang tata letak dan bentuk eksterior bangunan GPIB Immanuel-Jakarta bercorak bundar berdasarkan Adolf Heuken (1929 - 2019), mengimajinasikan "gereja gunung", sekalipun artifisial, tinggi tiga meter dari tanah dan membentuk bulatan dengan tiga sisi pintu masuk utama dan satu sisi pintu konsistorium. ${ }^{29}$ Gereja berlangit-langit tinggi tanpa menara namun berkubah ini menjadi daya tarik karena letaknya di area terbuka. Gereja berkesan "kosong" dan raksasa ini, berdasarkan Van de Ven, pada satu sisi memperlihatkan fungsi ketimbang keramaian ornamentasi dan dekorasi artifisial. ${ }^{30}$ Pada lain sisi menggambarkan reduksi ruang nir-batas dengan sekat, yakni dinding-dinding gereja, sehingga berkesan lebih "dekat" dan nyaman. ${ }^{31}$

Penyebutan gereja gunung adalah karena bangunan gereja berdiri tepat seukuran atau "gunung" lebih besar daripada gereja. Seukuran "gunung", artinya gereja adalah bagian "gunung". Ukuran "gunung" lebih besar, artinya gereja merupakan bagian atas dari "gunung". Intinya sama, masuk gereja adalah masuk gunung, tempat persemayaman Ilahi. ${ }^{32}$

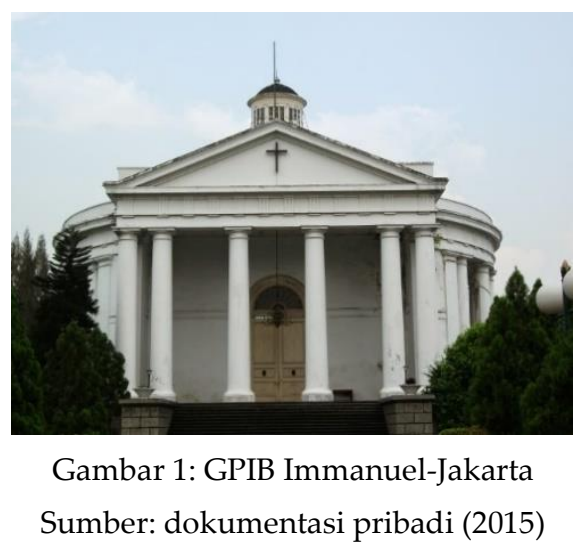

Contoh lain gereja batu berkesan "kosong" adalah Kapel Biara Bunda Pemersatu Gedono di Getasan-Jawa Tengah. Bentuk nyata "kosong" dari kawasan adalah karakter praksis keheningan monastik Trapistin. Arsitek kapel awal adalah RD. Y.B.

${ }^{29}$ Adolf Heuken, Gereja-Gereja Tua Di Jakarta (Jakarta: Cipta Loka Caraka, 2003), 134-135.

${ }^{30}$ Van de Ven, Ruang Dalam Arsitektur: Evolusi Dari Sebuah Gagasan Baru Dalam Teori Dan Sejarah Gerakan-Gerakan Modern, 61-62.

31 Ibid. 113-114; Heuken, Gereja-Gereja Tua Di Jakarta, 135.

32 Mangunwijaya, Wastu Citra: Pengantar Ke Ilmu Budaya Bentuk Arsitektur Sendi-Sendi Filsafatnya Beserta Contoh-Contoh Praktis, 98 dan 113, menyebut kosmos dengan mengacu pada gerbang Pura Hindu-Bali berbentuk meru (segitiga-utuh) atau Candi Bentar (gerbang terbelah). Kedua bentuk gerbang Pura selalu tak-tertutup; bnd. Takenaka, The Place Where God Dwells, 20. 
Mangunwijaya (Romo Mangun, 1929 - 1999),33 terutama bagian eksterior. Kapel ini (posisi paling kiri) merupakan bangunan tertinggi di antara dua ruang lain. Dinding dengan material batu merupakan ornamen khas "mengisi" kekosongan dan menimbulkan efek. ${ }^{34}$



Gambar 2. (kiri): Kapel Gedono; (kanan): tampak depan kapel

Sumber: dokumentasi pribadi (2008)

Kesan "kosong" tidak menjadikan sebuah bangunan tak estetis dan menyeramkan, sebab struktur bangunan mencipta keindahannya sendiri ${ }^{35}$ sebagaimana terlihat pada gereja segitiga. Harun Hadiwijono, berdasarkan ajaran Hindu-Siwa, menyatakan bahwa Siwa adalah Dewa tertinggi yang disamakan dengan kekosongan mutlak. Kekosongan mutlak adalah sunyata, tak dapat ditembus akal manusia, tak dapat digambarkan dan dirumuskan. ${ }^{36}$ Dalam ungkapkan sejajar, Stefanus Haryono berdasarkan Dionysius the Areopagite (460-520) mengalimatkan bahwa kehadiran Tuhan tidak ditentukan dari definisi imanen dan transenden. ${ }^{37}$ Dalam bahasa Indonesia dan Sansekerta, sunyata (kekosongan, nothingness [disejajarkan dengan kehampaan \{emptiness\}]) bermakna kenyataan, benar, dan sungguh. ${ }^{38}$

Bangunan kapel "gunung" dapat dibandingkan dengan bangunan pura Hindu-Bali di Kab. Bogor yang menonjolkan tubuh utama bangunan sebagai badan gunung. Memasuki rumah ibadah melewati gerbang utama, baik berupa pintu maupun segitiga adalah memasuki mikrokosmos ${ }^{39}$ atau jagat cilik.

33 Bambang Setyawan, “Begini Heningnya Pertapaan Bunda Pemersatu Gedono,” diakses 15 September 2021, https://www.kompasiana.com/bamset2014/57bc03e4ed9673c50f3818ae/beginiheningnya-pertapaan-bunda-pemersatu-gedono?page=2\&page_images=1.

34 Van de Ven, Ruang Dalam Arsitektur: Evolusi Dari Sebuah Gagasan Baru Dalam Teori Dan Sejarah Gerakan-Gerakan Modern, 122-123.

35 Ibid, 71.

${ }^{36}$ Harun Hadiwijono, Konsepsi Tentang Manusia Dalam Kebatinan Jawa Uakarta: Sinar Harapan, 1983), 27-28.

37 Stefanus Christian Haryono, "Kehampaan (Nothingness): Sebuah Jalan Interspiritualitas," Gema Teologika 6, no. 1 (2021): 1-16.

38 Ibid, 9-10, berdasarkan Nitisani Keiji (abad kedua puluh).; "Kamus Besar Bahasa Indonesia Versi Daring, s.v. "sunyata"; Kamus Bahasa Sansekerta-Indonesia versi daring, s.v. "sunyata”."

${ }^{39}$ Nicholas W Roberts, Building Type Basics for Places of Worship (Hoboken: John Wiley \& Son, Inc, 2004), 11-12, mengutip Mircea Eliade. 




Gambar 3: gerbang meru di Pura Hindu-Bali, Ciapus-Kab. Bogor; sumber: dokumentasi pribadi (2013)

Perjanjian Lama menarasikan gunung sebagai tempat kediaman Allah (Kel. 24:15-17; Ul. 33:12; Mzm. 36:7; 48:3; 68:16; Yes. 2:2; Yeh. 28:14; Mi. 4:1; Za. 8:3) dan allah (1Raj. 20:23; Hos. 4:13), sehingga sering menjadi tempat ibadah (Kel. 3:12; 1Raj. 19:11; Mzm. 3:5; 24:3; 43:3) dan tempat tinggal (Kel. 18:5; 19:2; Mzm. 15:1; 30:8; 87:1; Yeh. 40:2). ${ }^{40}$ Gunung Horeb atau gunung Sinai (Kel. 3:1; 17:6; Ul. 4:10; 1Raj. 19:8; Mal. $4: 4$ ) adalah gunung kudus yang dijumpai oleh umat Israel dalam perjalanan ke tanah perjanjian. Kisah gunung kudus Gerizim ${ }^{41}$ masih tertinggal dalam percakapan Yesus dengan perempuan Samaria (Yoh. 4:20).

Dalam budaya Jawa, gunung mengandung roh atau tempat persemayaman dewa atau kahyangan. Peningkatan bangunan dari tanah hingga mengerucut yang terpola pada gereja gunung dan bermenara lancip dapat disejajarkan dengan konsep punden berundak pada candi. Sekalipun tidak serupa bentuknya, namun, berdasarkan Erik Hariansah, sejajar dengan pemahaman bahwa Sang Ilahi atau leluhur bersemayam di tempat tertinggi yang terpola pada bangunan. ${ }^{42}$ Dalam pemikiran Hindu di Jawa, menurut Hadiwijono, Siwa menjelmakan diri dalam bentuk jagat gedhe, yakni dua belas tatwa (keadaan yang sesungguhnya, kenyataan) dan jagat cilik, yakni manusia. Manusia, dalam pemikiran Hindu dan Budha menjadi tempat kediaman Yang Ilahi. ${ }^{43}$ Pada satu sisi, gunung, atau lazim disebut sri gunung, menampakkan keanggunan dan kewibawaan dari kejauhan. Mangunwijaya mempertegas bahwa gunung juga mengesankan kestabilan; besar di bawah, semakin mengerucut ke atas. ${ }^{44}$ Menurut Hadiwijono, Sri

40 D F Walker, "gunung", Konkordansi Alkitab: Register Kata-Kata Dan Istilah Dari Alkitab Perjanjian Lama Dan Perjanjian Baru Dalam Terjemahan Baru (Jakarta: BPK Gunung Mulia, 2018).

${ }^{41}$ Lembaga Alkitab Indonesia, Alkitab Edisi Studi, Yohanes 4, ket. 4:20, 1733 .

42 Erik Hariansah, "Punden Berundak, Arsitektur Asli Leluhur Nusantara," diakses 15 September 2021, https://attoriolong.com/2019/09/punden-berundak-arsitektur-asli-leluhur-nusantara/.

43 "tatwa", Kamus Bahasa Sansekerta-Indonesia Versi Daring, http://www.sansekerta.org/kamussansekerta/,; Hadiwijono, Konsepsi Tentang Manusia Dalam Kebatinan Jawa, 33-34 \& 39.

44 Mangunwijaya, Wastu Citra: Pengantar Ke Ilmu Budaya Bentuk Arsitektur Sendi-Sendi Filsafatnya Beserta Contoh-Contoh Praktis, 315-316. 
adalah Laksmi, jelmaan istri Wisnu, yakni bunda asal (mother's earth). ${ }^{45}$ Memandang bangunan gereja adalah laksana memandang bunda dengan sosok anggun, berwibawa, dan tegas.

Pada lain sisi, dalam pemahaman bunda asal, sri gunung mengandung potensi besar bagi kehidupan dan kelangsungan bumi. ${ }^{46}$ Takenaka, berdasarkan informasi Wayan Mastra (Bishop GKPB), menuliskan perihal potensi gunung, yaitu: api dari kawah gunung berapi, angin dari puncak gunung, dan air segar dari danau vulkanik. ${ }^{47}$ Satu lagi, sebagaimana Cornelis van de Ven berdasarkan Plato, adalah tanah. Hasil olahan keempat unsur: api, air, udara, dan tanah secara proporsional membentuk dunia (bnd. Kej: 2:5-7 "tanah, kabut basah, dan embusan nafas") dan ruang, yakni bangunan. ${ }^{48}$

Merencanakan pembangunan gereja "gunung" memiliki tantangan tersendiri, sekalipun tantangan ini tidak menafikan arti maknawinya. Pada satu sisi, gereja perlu mengondisikan jalur umat menuju medan daya, yakni ruang dalam liturgi. Pada lain sisi, gereja tertantang menyediakan akses bagi kaum disabilitas kaki dan anggota gerak, baik berkursi roda, bertongkat, atau bertatih-tatih.

James White dan Susan White memberi panduan perihal jalan masuk khusus dengan ramps, pegangan tangan, pintu-pintu, pembedaan warna lantai, anak tangga, dan railings yang berterima bagi lanjut usia, disabilitas kaki, anak dengan diabilitas, dan anak. ${ }^{49}$ Penyediaan ruang parkir mobil, motor, kendaraan empat roda (ATV [All Terrain Vehicle]) berkapasitas lebih lapang bagi disabilitas juga seharusnya menjadi perhatian gereja dari jalan, pelataran, dan akses menuju ke semua ruang dalam gereja. ${ }^{50}$ Padahal menurut Amos Yong, aksesibilitas barulah tahap pertama bagi gereja inklusif bagi penyandang disabilitas. Intinya, gereja keliru jika melihat bahwa hanya sedikit umatnya yang disabilitas, ${ }^{51}$ melainkan gereja tak menyediakan akses bagi kaum disabilitas. ${ }^{52}$

\footnotetext{
${ }^{45}$ Hadiwijono, Konsepsi Tentang Manusia Dalam Kebatinan Jawa, 21.

46 Dewi Sundari, "Pribahasa Jawa - Sri Gunung," diakses 21 April 2021, https: //www.dewisundari.com/.

47 Takenaka, The Place Where God Dwells, 19.

${ }^{48}$ Van de Ven, Ruang Dalam Arsitektur: Evolusi Dari Sebuah Gagasan Baru Dalam Teori Dan Sejarah Gerakan-Gerakan Modern, 9.

${ }^{49}$ James F. White dan Susan J. White, Church Architecture: Building and Renovating for Christian Worship (Nashville: Abingdon Press, 1989), 152-153.

${ }^{50}$ Roberts, Building Type Basics for Places of Worship, 93-94. Berdasarkan the American with Disabilities Acts (ADA) 1990 .

${ }^{51}$ Susan J. White and James F. White, Church Architecture: Building and Renovating for Christian Worship (Nashville: Abingdon Press, 1989), 154. \%. Namun, Fachri Fachrudin, Okezone, "Penyandang Disabilitas di Indonesia Mencapai 9 Juta Jiwa," https://nasional.okezone.com/read/2015/12/03/ 337/1260124/ penyandang-disabilitas-di-indonesia-mencapai-9-juta-jiwa (diakses 1 Mei 2021) memberikan data (Desember 2015) berdasarkan BPS 2010: "Untuk disabilitas yang kesulitan berjalan atau menaiki tangga, kategori ringan berjumlah 2.432 jiwa sementara kategori parah sebanyak 656 jiwa," tambah "disabilitas yang kesulitan mengurus diri sendiri dalam kategori ringan sebanyak 1.511 jiwa sedangkan kategori parah berjumlah 533 jiwa.

${ }^{5}$ Amos Yong, The Bible, Disability, and the Church: A New Vision of the People of God (Grand Rapids: William B. Eerdmans Publisihing Company, 2011); Sweety, "Sekolah Minggu Ramah Anak Dengan
} 
Berkaca pada paparan Frick, hal yang perlu mendapat tekanan bagi gereja "gunung" zaman modern adalah belajar dari arsitektur tradisional. Arsitektur tradisional telah memperlihatkan hubungan harmonis dengan lingkungan sekitar, baik manusia, sejarah, maupun alam. ${ }^{53}$ Modernitas bangunan gereja masa kini kelak akan meninggalkan jejak gereja ramah atau pongah terhadap lingkungan sekitar.

\section{Menara adalah tugu yang melumbung}

Perjalanan umat Israel di gurun pasir diisi dengan kisah mendirikan batu sebagai tugu peringatan. Penulis Alkitab mempersaksikan bahwa "tugu itu masih berdiri hingga kini“ (bnd. Kel. 28:18; Yos. 4:7-9 di tepi sungai Yordan, 20-24 di Gilgal; 1Sam. 7:12 Eben-

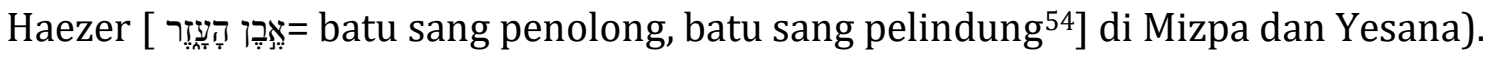

Tugu atau tiang dalam budaya masyarakat merupakan pusat lingkaran yang menjadi kiblat. Umat Israel berjalan mengikuti TUHAN dalam tiang awan dan tiang api (Kel. 13:21-22; Bil. 14:14). Berdasarkan informasi Sivertsen, awan dan api tersebut merupakan lontaran abu vuklanik erupsi gunung Arabia yang terjadi beberapa pekan atau bulan. ${ }^{55} \mathrm{Hal}$ tiang api ini telah dinarasikan dalam prosesi awal liturgi, ${ }^{56}$ namun bentuk-luar mengisahkan struktur secara berbeda.

Mangunwijaya memaparkan bahwa tugu atau tiang merupakan poros pohon, salah satu citra-dasar. Tugu adalah medan daya bagi sekitar. ${ }^{57}$ Pusat lingkaran bercorak mandala memiliki daya gaib sebagai medan daya, medan energi, atau medan magnet. Laksana pusar ibu bagi bayi, medan daya itu merupakan sumber kehidupan bagi lingkaran sekitar. KBBI memperjelas bahwa mandala bermakna: wilayah kekuasaan lembaga keagamaan, dan bentuk: bulatan, lingkungan (daerah). Heinz Frick memperjelas gambaran pusar sebagai pusat lingkaran dengan ilustrasi ukuran dan proporsi perbandingan 1:1 sebagai dasar simetri.

Pusar terletak di tengah lingkaran rentangan tangan dan kaki manusia. Pada dirinya, berdasarkan Timbul Raharjo, tugu merupakan jagat cilik atau mikrokosmos, yakni manusia atau masyarakat. Jagat cilik adalah bentuk nyata bersekat dari jagat gedhe atau makrokosmos, yakni alam semesta. Menurut Hadiwijono berdasarkan ajaran

Disabilitas: Studi Kasus Terhadap Praktik Sekolah Minggu Di Gereja Kristen Indonesia Gunung Sahari Jakarta" (tesis, M.Th., Sekolah Tinggi Filsafat Theologi Jakarta, 2019), 21-23. mengutip Joice Ann Mercer Welcoming Children tentang empat tahap sikap ramah gereja terhadap anak dengan disabilitas, yaitu: welcoming (menyambut), chalenging (menantang), celebrating (merayakan), enfolding (merengkuh) .

${ }^{53}$ Heinz Frick, Arsitektur Dan Lingkungan (Yogyakarta: Kanisius, 1994), 84.

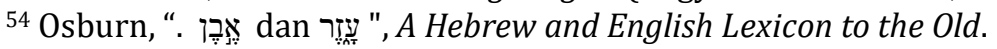
Exodus, 60.

55 Sivertsen, The Parting of the Sea: How Volcanoes, Earthquakes, and Plagues Shaped the Story of

56 Rasid Rachman, "Tata Ruang Dalam Gereja Yang Secara Liturgis Menarasikan Karya Allah," Jurnal Theologia in Loco 3, no. 1 (2021): 53.

57 Mangunwijaya, Wastu Citra: Pengantar Ke Ilmu Budaya Bentuk Arsitektur Sendi-Sendi Filsafatnya Beserta Contoh-Contoh Praktis, 97-98 dan103. 
Hindu-Jawa, alam semesta sebagai jagat gedhe pada hakikatnya adalah dewa tertinggi, yakni Siwa dan Mahayana. ${ }^{58}$ Alam semesta menyediakan:

"arah mata angin yang selalu menyertai di mana pun manusia bergerak. Mata angin sebagai kiblat sedulur papat, yaitu: lor (utara), wetan (timur), kulon (barat), dan kidul (selatan), merupakan arah yang selalu menuntun manusia untuk menguasai dan hidup bersama dengan alam semesta. ${ }^{59}$

Pusat lingkaran masyarakat, Raharjo mengambil budaya Yogyakarta, adalah raja, keraton, dan kota Yogyakarta. Keempat kabupaten Yogyakarta: Sleman, Wonosari, Kulonprogo, dan Bantul, mengarah ke tugu, maka terwujudlah kiblat sedulur papat lima pancer, ${ }^{60}$ arti bebas: kiblat (dari) empat saudara (dan yang) kelima (adalah) pusat. Empat saudara itu, menurut Dewi Sundari menelisik falsafah Jawa tentang kelahiran bayi, merupakan penjaga dan pengawal sang bayi agar bayi tetap hidup. ${ }^{61}$

Vertikalisme tugu kemudian membentuk menara. Mangunwijaya memperlihatkan falsafah lumbung Minang yang bukan hanya menjulang vertikal, tetapi juga disanggah oleh balok dan batang horizontal. Tiang atau atap melancip menunjuk kepada Yang Mahakuasa, sedangkan "balok horizontal menunjuk kepada alam sekitar dan sesama manusia."62 Pola tugu dan kemudian lumbung ini menyerupai pola dasar bangunan gereja.



Gambar 4.: Lumbung “Tirto Meciho” rumah Gunung di Sibolangit Sumber: dokumentasi pribadi (2014)

Berdasarkan bentuk bangunannya - mari bayangkan kalimat kiasan ini - "badan gereja berawal dari narasi tugu lancip atau menara menjulang tinggi yang kemudian melumbung," bukan melambung. Secara kuantitatif ukuran lumbung kecil, namun

58 Hadiwijono, Konsepsi Tentang Manusia Dalam Kebatinan Jawa, 33-35 dan 36-37.

59 Timbul Raharjo, "Kiblat Papat Lima Pancer," Laporan Penciptaan Seni Rupa Dalam Rangka Pameran Seni Visual: Memaknai Pusat, Pameran Foto, Sketsa, Sejarah, Dan Karya Seni Rupa Tentang Tugu Jogja Di Jogja Gallery Jl. Pekapalan 7 Alun-Alun Utara tanggal 21 Juli - 20 Agustus 2012 (Yogyakarta, 2012), 11.

60 Ibid, 13.

61 Dewi Sundari, “Apa Itu Sedulur Papat Lima Pancer?,” diakses 22 April 2021, https://www.dewisundari.com/.

62 Mangunwijaya, Wastu Citra: Pengantar Ke Ilmu Budaya Bentuk Arsitektur Sendi-Sendi Filsafatnya Beserta Contoh-Contoh Praktis, 31. 
bercitra secara kualitatif. Mangunwijaya menarasikan bahwa lumbung mencitrakan jiwa yang mengerti keindahan, kewajaran, kejujuran, keluwesan, dan budi bahasa. Potensi di dalam "tubuh" lumbung menyimpan kebutuhan hidup manusia63 (bnd. Kej. 41:34-57 kisah lumbung Yusuf di Mesir). Kehadiran gereja bukan hanya memperindah dunia secara estetis, tetapi juga peran sosialnya sebagai sila. ${ }^{64}$ Keindahannya bukan karena bangunan gereja bermenara melambung dan berbadan kembung, melainkan karena gereja adalah "menara" yang melumbung.

Gereja "lumbung" berada dalam pemahaman gereja sebagai pengarah umat menuju sacred center sebagai kiblat. Gereja "lumbung" adalah gereja kiblat. Catherine Bell mengangkat dua hal tentang ziarah mengarah ke sacred center, yaitu: pergerakan menuju kosmos tertata atau pergerakan melampaui ancaman kekelaman untuk menerima tawaran kebaikan.65 Gereja adalah kiblat umat meninggalkan kekelaman menuju ke penataan hidup. Sebagaimana tanah perjanjian "lumbung susu dan madu" (Kel. 3:8; Ul. 26:9; bnd. Ul. 32:13-14), tantangan gereja adalah menjadi minat umat mengarah kepada tawaran ritual yang disajikan oleh bangunannya. ${ }^{66}$ Gereja menjadi daya tarik umat terutama bukan pada "madu", melainkan pada nilai di dalamnya (bnd. Mzm. 19:10-11 "hukum TUHAN lebih manis daripada madu"). ${ }^{67}$

Roberts mempertegas paparan ini tentang konsep gereja "lumbung"sebagai axis mundi (pusat bumi). ${ }^{68}$ Mircea Eliade memperjelas bahwa axis mundi merupakan pemusatan konsentrasi (centre of the world) pada tempat sakral (imago mundi) atau Yang Kudus (bnd. Mzm. 97:2). Pusat atau tengah menarasikan penciptaan dunia yang bermula dari embrio. Gambaran pemusat atau penengah dalam banyak kepercayaan adalah dengan mandala. ${ }^{69}$ Gerak mandala tampil dalam prosesi mengelilingi, semisal: pradaksina, yaitu ritual sembahyang dengan berputar tiga kali searah jarum jam mengelilingi Candi Borobudur atau candi lain; ${ }^{70}$ tawaf berjalan berlawanan arah jarum jam tujuh kali di sekitar Ka'bah; ${ }^{71}$ dan kota Yerikho dalam prosesi memasuki tanah perjanjian (Yos. 6:3-19). Pola mandala, menurut Eliade, juga berarti perlindungan (bnd.

63 Ibid, 30-31.

64 " sila": 1) aturan yang melatarbelakangi perilaku seseorang atau bangsa; 2) kelakuan atau perbuatan yang menurut adab (sopan santun); 3) dasar; adab; akhlak; moral, Kamus Besar Bahasa Indonesia Versi Daring, diakses 29 April 2021.

65 Catherine Bell, Ritual: Perspectives and Dimensions (New York: Oxford University Press, 1997), 249.

66 Ibid, 249-250.

67 Ibid, 250.

68 Roberts, Building Type Basics for Places of Worship, 12.

69 Mircea Eliade, Images and Symbols: Studies in Religious Symbolism, Terj. Philip Mairet, ed. Philip Mairet (Princeton: Princeton University Press, 1991), 51-52; “"mandala”: 1) wilayah kekuasaan lembaga keagamaan; 2) bulatan, lingkungan (daerah)Kamus Besar Bahasa Indonesia Versi Daring."

70 Veda School of Wisdom and Knowledge, "Pradakshina or Parikrama in Ancient Ritual," https://vedapathshala.com/2020/06/23/pradakshina-circumambulation/; Eliade, Images and Symbols: Studies in Religious Symbolism, Terj. Philip Mairet, 52-53.

71 Hasuna, “Apa Itu Tawaf, Jenis-Jenis, Tata Cara, Dan Sunnah Pelaksanaannya," diakses 15 September 2021, https://hasuna.co.id/apa-itu-tawaf/. 
Mzm. 34:8 Malaikat TUHAN berkemah di sekeliling orang-orang yang takut akan Dia, lalu meluputkan mereka"; Mzm. 125:2). ${ }^{72}$

\section{Tepi air sebagai magico-religious dan penyeberangan}

Perjalanan umat Israel ke tanah perjanjian mengalami beberapa perhentian di tepi-tepi air. Setiap perhentian mengandung narasi penyelamatan yang Allah lakukan. Perjalanan memasuki gurun pasir terhalang oleh teberau (Kel. 13:18). Perhentian di Pi-Hahirot di tepi laut (Kel. 14:1-2) memperlihatkan penyelamatan oleh Allah atas serangan pasukan Firaun. Perhentian di Elim mengakhiri kehausan perjalanan tiga hari tanpa air hingga mendapat minum di Mara (Kel. 15:22-27). Perhentian di tepi sungai Yordan untuk membuat strategi memasuki Kanaan (Yos. 3). Air bermakna penyelamatan (Mzm. 114:8), perlindungan dan kehidupan makmur (Bil. 13:25-31), bukan seperti Mesir dan padang gurun. Air adalah pembatas antara sebelum dan keakanan.

Bagi masyarakat kuno, padang gurun, dataran tinggi, laut, sungai, gunung, lembah (Bil. 34:3-12; Yos. 13:8-31; 15:2-12; Yeh. 47:1; bnd. Luk. 16:26 "jurang tak terseberangi“) merupakan batas teritori natural. Ada juga batas tak-natural, semisal: pagar, pancang, gerbang, jalan, kolam, keran pancur, atau penyediaan air suci, selain pohon dan tugu (bnd. Kej. 31:44-45, 51-52). Sivertsen menginformasikan bahwa pembatasan wilayah sekitar Laut Mati secara bertahap terjadi sekitar abad kelima belas hingga ketiga belas SM atau Zaman Perunggu Muda (Late Bronze Age). ${ }^{73}$

Menyeberangi sungai dalam beberapa kebudayaan, menurut Arnold van Gennep, adalah ritus berkonotasi negatif, sehingga merupakan larangan bagi raja atau ratu, karena melanggar batas. ${ }^{74}$ Kisah tepi air dan penyeberangan dalam Alkitab umumnya berupa pengajaran akan perubahan dari sebelum ke keakanan, semisal: pemulihan, penyembuhan, pengalaman, atau paradigma. ${ }^{75}$ Umumnya, rumah ibadah, termasuk gereja, membuat teritori air buatan. Pembatas buatan ini kemudian malah menjadi efektif ketimbang pembatas natural. Umat Israel tak boleh melewati batas ketika TUHAN hadir (Kel. 19:12-13, 21-23).

Beberapa bangunan gereja masa kini membuat batas teritori, magico-religious, ${ }^{76}$ kasat mata dengan bangunan rumah ibadah agama lain. Beberapa bangunan gereja mendirikan pagar atau jalan sebagai batas teritori dengan rumah ibadah lain, atau ruang lain, semisal: mal, kantor, pasar, pom bensin, sawah, dsb. Van Gennep memperjelas

\footnotetext{
${ }^{72}$ Eliade, Images and Symbols: Studies in Religious Symbolism, Terj. Philip Mairet, 53.

${ }^{73}$ Sivertsen, The Parting of the Sea: How Volcanoes, Earthquakes, and Plagues Shaped the Story of Exodus, 112-113.

${ }^{74}$ Arnold Van Gennep, The Rites of Passage, terj. Gabrielle L. Caffee and Monika B.Vizedom (Chicago: The University of Chicago Press, 1992), 22-23.

${ }^{75}$ L.Michael White, The Social Origins of Christian Architecture, Volume II: Texts and Monuments for the Christian Domus Ecclesiae in Its Environment (Valley Forge: Trinity Press International, 1997), 21.

${ }^{76}$ Van Gennep, The Rites of Passage, 15.
} 
bahwa magico-religious kasat mata merupakan cermin dari magico-religious tak kasat mata. Intinya, batas teritori tak boleh dilewati, atau merupakan penistaan. ${ }^{77}$

Hal larangan atau tabu melewati teritori "batal" hanya jika, demikian van Gennep melanjutkan, melakukan ritus penyeberangan (portal ritual). ${ }^{78}$ Ritus pintu terlihat dalam tindakan wudu, ${ }^{79}$ peringatan pada pembaptisan di pintu masuk, atau asperges me, sebelum liturgi Ekaristi (Mzm. 51:9 "bersihkanlah aku"; bnd. Hak. 12:5-6 "syibolet" atau sibolet"). ${ }^{80}$ Jajaran keran untuk wudu terlihat pada eksterior Gereja Hati Kudus Tuhan Yesus Ganjuran, Bantul-Yogyakarta. Keran wudu terletak di depan area candi yang berisi patung Maria dan Yesus. Eusebius Kaisarea (300 - \pm 338), dalam Historia Ecclesiastica mendeskripsikan pembangunan gereja antara 317 dan 324 di Tirus. Ia menjelaskan antara lain penyediaan ruang terbuka dengan air mengalir sebagai stasi pertama bangunan ibadah (bnd. Yeh. 47:1 "air mengalir dari ambang pintu Bait Suci“). Sebelum melewati pintu masuk, umat membersihkan diri dengan air itu. ${ }^{81}$ Keterangan Eusebius ini diperkuat dengan bangunan gereja antara zaman Patristik hingga sekitar masa Reformasi yang menempatkan baptisterium sekitar pintu masuk gereja.

Pertemuan jemaat di tepi air telah ada sejak awal kekristenan. Para Penginjil, sebagaimana paparan Edward Adams, beberapa kali mengisahkan pertemuan jemaat di tepi air. ${ }^{82}$ Tepi air adalah tempat penampakan Ilahi. Beberapa peristiwa tepi air dikisahkan dalam Alkitab, semisal: pertarungan Yakub di tepi Sungai Yabok (Kej. 32:2326), pembaptisan Yesus di sungai Yordan (Mrk. 1:9-10), percakapan Yesus dengan perempuan Samaria di sumur Yakub (Yoh. 4), perjumpaan Yesus dengan orang sakit di kolam Betesda (Yoh. 5:1-9), Yesus memberi makan lima ribu laki-laki dalam persekutuan di danau Tiberias (Yoh. 6:1-14, 22-24), penampakkan Yesus di pantai danau Tiberias (Yoh. 21:1). Banyak tampilan liturgi dan bangunan gereja di tepi air sepanjang sejarah;83 semuanya tak perlu saya kemukakan di sini.

Perkemahan tepi air banyak dikisahkan dalam perjalanan di padang pasir (Bil. 33:5-49), antara lain: Elim, gurun Sinai, Rafidim. ${ }^{84}$ Di ujung perjalanan di padang gurun, Yosua dan umat Israel berhenti singgah di tepi sungai Yordan (Yos. 3:1). Misi mereka adalah mengatur strategi, menyeberangi sungai, dan memasuki tanah Kanaan. Tepi

\section{Ibid, 15-16.}

78 Ibid, 22-24.

79 "wudu": (Isl.) menyucikan diri (sebelum salat) dengan membasuh muka, tangan, kepala, dan kaki Kamus Besar Bahasa Indonesia Versi Daring"; Roberts, Building Type Basics for Places of Worship, 11, mencuci tangan dan mulut juga terdapat dalam Shinto dan Budha.

80 Ernest Maryanto, "air suci"; "asperges"; "asperges me”, Kamus Liturgi Sederhana (Yogyakarta: Kanisius, 2004); J.G. Davies, "Asperges", The New Westminster Dictionary of Liturgy and Music (Philadelphia: SCM Press, 1986).

81 White, The Social Origins of Christian Architecture, Volume II: Texts and Monuments for the Christian Domus Ecclesiae in Its Environment, 95 dan 98.

82 Edward Adams, The Earliest Christian Meeting Places: Almost Exclusively Houses?, Revised. (London: Bloombury T\&T Clark, 2016), 186-187.

83 Ibid, 188.

${ }^{84}$ Lembaga Alkitab Indonesia, Alkitab Edisi Studi, 275. 
sungai dalam teks Alkitab bukan tujuan, melainkan persinggahan untuk meneruskan perjalanan atau menyeberang.

Penempatan bejana baptis di antara pintu masuk dan area umat, seperti GKJ Purwodadi-Jawa Tengah dan Gereja St. Fransiskus Asisi Berastagi-Sumatera Utara, menggambarkan air sebagai batas teritori dan ritus pintu. 85 Nicholas Roberts menarasikan bahwa baptisan merupakan penghubung dan pengantara umat dari luar memasuki gereja dan menuju firman. ${ }^{86}$

Sebagaimana gereja dengan penyambut (usher), ${ }^{87}$ ritus pintu juga dilakukan oleh masyarakat tradisional. Ritus berbalas pantun di depan pintu rumah mempelai perempuan budaya Melayu, atau palang pintu budaya Betawi dengan petasan, adu pantun, silat, dan shalawat merupakan salah satu contoh. ${ }^{88}$ Dalam keseharian portal ritual dijumpai, misalnya ritus exit permit dan visa kunjungan perbatasan (frontier) dua negara; mengisi buku tamu dalam perhelatan; bayar tiket masuk tempat wisata; berseru: "Sepada," di depan rumah tetangga. Ritus pintu di batas teritori merupakan ritus lazim dalam kehidupan sosial. Artinya, "Silakan masuk, kamu berterima di teritori kami." Letak gereja umumnya di tepi jalan menggambarkan gereja yang dapat dimasuki dengan mudah (bnd. Ayb. 31:32). ${ }^{89}$

Beberapa gereja berlokasi di tepi air alami, semisal: GKI Pamulang-Tangerang Selatan. Dari sudut tertentu, terpampang tampilan bangunan gereja "berlayar" tersebut. Yang terlihat adalah laksana haluan yang akan memunculkan seluruh badan kapal atau

85 Roberts, Building Type Basics for Places of Worship, 42, bnd. 39, mempertunjukkan gambar bejana baptis di sekitar pintu masuk di United Methodist Church, Charles City-Iowa; Rachman, "Tata Ruang Dalam Gereja Yang Secara Liturgis Menarasikan Karya Allah" 48-49. rancangan

86 Roberts, Building Type Basics for Places of Worship, 45, denah atas dan denah bawah sebagai

${ }^{87}$ Rachman, "Tata Ruang Dalam Gereja Yang Secara Liturgis Menarasikan Karya Allah,"49.

88 Theodorus Budiarjo Lahama, "Mengenal 'Palang Pintu', Tradisi Orang Betawi," diakses 21 April 2021, https://muda.kompas.id/baca/2018/07/04/mengenal-palang-pintu-tradisi-orang-betawi/.

89 Takenaka, The Place Where God Dwells, 20-21. 




Gambar 5 (kiri) GKI Pamulang, Tangerang Selatan; sumber: dokumentasi pribadi (2021)

Gambar 6 (kanan): keran wudu di Gereja HKTY, Ganjuran; sumber: dokumentasi pribadi (2014)

bahtera. Tak lama lagi, akan muncul "kapal”. Van de Ven mempertegas, berdasarkan pemikiran Aristoletes perihal tempat nir-bentuk dan nir-wujud namun terlingkung oleh kawasan tak-kasat mata, bahwa tempat yang dapat "bergerak". ${ }^{90}$ Arsitek modern memanipulasi nir-sekat bangunan dengan partisi, jendela besar, kaca atau cermin, dan pintu geser. Dalam dunia hukum, kawasanbergerak terlihat pada kapal laut militer. Selama di laut bebas, kapal laut militer adalah kawasan negara kapal tersebut berasal.

Kendalanya, pengendapan air dan kondisi lahan tidak memungkinkan pemberlakuan bangunan di tepi air alami. Namun, inti ide gereja bergerak atau bergulir adalah bukan pada ide ruang berbentuk kapal atau biduk sebagaimana bangunan gereja tepi air. Bangunan gereja sebagai perangkat arsitektur, menurut Van de Ven berdasarkan Theo van Doesburg (awal abad kedua puluh), bersifat kontinuum ruang dan waktu. ${ }^{91}$ Sifat kesinambungan ruang-waktu itu menggambarkan gereja eksodus yang bergulir. Ide moving church (ekklesia ambulare) juga muncul dalam bentuk arsitektur kemah (bnd. 2Sam. 7:6 dan 1Taw. 17:5) dalam paparan berikut.

Pergerakan gereja ditampilkan oleh pergerakan umat sebagai prima performa. Bangunan gereja menyaranai pergerakan sejak bagian luar bangunan dengan jalur yang mengondisikan umat berprosesi. Secara maknawi, mengacu pada paparan Scott Paeth, gereja eksodus adalah gereja yang menempatkan umat sebagai subjek keadilan, perdamaian, keutuhan ciptaan di dalam masalah sosial dan tata masyarakat demi tujuan menyambut datangnya Kerajaan Allah. ${ }^{92}$ Peran umat di dunia nyata dan modern itu,

90 Van de Ven, Ruang Dalam Arsitektur: Evolusi Dari Sebuah Gagasan Baru Dalam Teori Dan Sejarah Gerakan-Gerakan Modern, 18, 20-21.

91 Ibid, 243.

92 Scott R Paeth, Exodus Church and Civil Society: Public Theology and Social Theory in the Work of Jürgen Moltmann (Burlington: Ashgate Publishing Company, 2008), 23-24. 
menurut Paeth berdasarkan Jürgen Moltmann, harus non-identitas Kristen, ber-kenosis (кعvós), atau teologi salib (theologia crucis) yang bertolak belakang dengan teologi kemuliaan (theologia gloriae). Jika umat berperan tanpa mengosongkan diri, maka gereja hanya menjadi tameng dan persembunyian. ${ }^{93}$

Kembali pada aksioma di awal tulisan ini - kali ini tidak lagi pemeo - gereja adalah umatnya. Hingga akhir Abad-abad Pertengahan, White dan White mempertegas bahwa interior gereja tanpa kursi memfasilitasi gerak "bebas" umat selama beribadah. Gambaran gereja bergerak adalah inti teologi ibadah. ${ }^{94}$ Bergerak, sebagaimana alam semesta, adalah hakikat Allah (bnd. Za. 9:8 TUHAN memilih tinggal di kemah ketimbang rumah-Nya) dan identitas selebrasi liturgi umat. Pulau-pulau pun mengalami evolusi melalui gesekan lempeng kulit bumi dan pancuran perut bumi. Jika selebrasi ibadah beberapa gereja hanya menyediakan sedikit ruang bergerak dan berprosesi, ${ }^{95}$ maka setidaknya bangunan gereja menggambarkan deskripsi non-verbal gereja yang berjalan.

\section{Kemah mengesankan sejenak berhenti}

Segitiga menyimbolkan Kemah Suci atau Kemah Pertemuan (Bil. 1:50; Ul. 31:14-15) atau tenda perteduhan umat Israel selama perjalanan di padang pasir (Kel. 14:1-4; 19:1-2; Bil. $1: 50-54 ; 2: 1-2 ; 10: 31-34)$. Bagi umat Israel, pengenalan pertama akan TUHAN terjadi di perkemahan di depan gunung Sinai (Kel. 19:1-3). Secara maknawi, berdasarkan Dozeman, Israel bersemuka di hadapan TUHAN. ${ }^{96}$ Memori akan kemah terus dibawa hingga Israel menjadi masyarakat penetap di kota (Hak. 20:8; 1Sam. 13:2; 1Raj. 8:66), ${ }^{97}$ sebagai narasi orang Yahudi melalui perayaan Pondok Daun (Im. 23:34; Ul. 16:13; Za. 15:16), dan direnarasikan oleh gereja melalui bangunan berbentuk kemah. Ciri menonjol eksterior bangunan kemah adalah segitiga melancip di puncak.

Contoh bangunan gereja berbentuk kemah antara lain: GPIB Maranatha di

${ }^{93}$ Ibid, 28.

${ }^{94}$ Susan J. White and White, Church Architecture: Building and Renovating for Christian Worship, 26-27. Allah." 53.

95 Ibid. 28-29; Rachman, "Tata Ruang Dalam Gereja Yang Secara Liturgis Menarasikan Karya ${ }^{96}$ Dozeman, God on the Mountain: A Study of Redaction, Theology and Canon in Exodus 19-24, 1516.

\footnotetext{
${ }^{97}$ De Vaux, Ancient Israel: Its Life and Institutions, 13.
} 


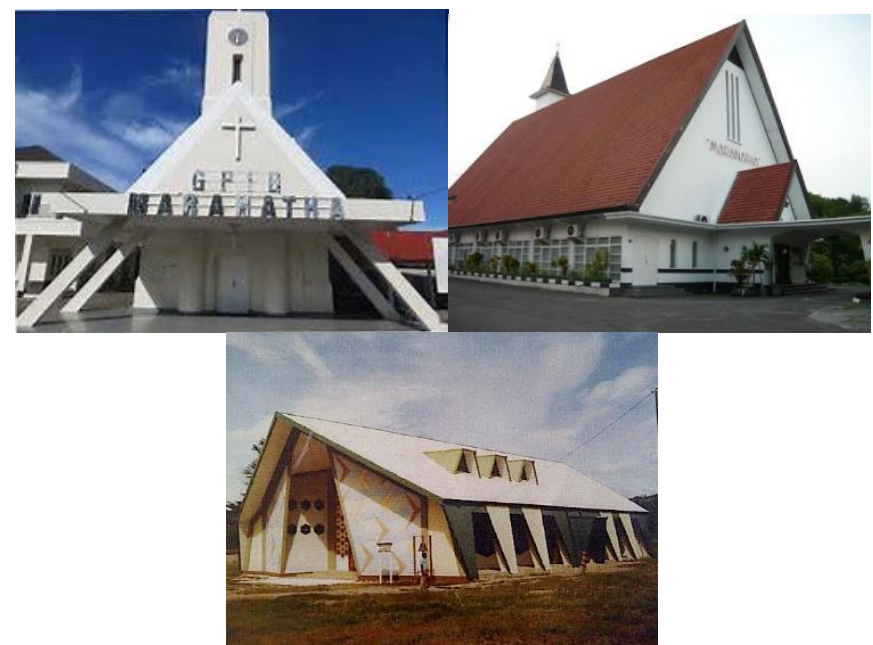

Gambar 7: GPIB Maranatha Bangka (kiri), GPIB Maranatha Surabaya (kanan), dan Gedung Gereja Kota Raja, Distrik Abepura (bawah)

Pangkalpinang-Bangka, GPIB Maranatha-Surabaya, ${ }^{98}$ Gereja Kota Raja, dan GKI GresikJawa Timur. Gereja Kota Raja (artinya: seperti Mahkota Raja, arsitek: Br. Henk Blom, OFM), karena melihat dari kejauhan gedung gereja tersebut seperti mahkota seorang Raja, ${ }^{99}$ terkesan berbentuk kemah. Struktur tiang-tiang di sisi kanan-kiri gereja kemah tersebut menarasikan tali-tali pasak kemah.100 Kesan sebagai kemah cukup kentara. Gereja Bangka dan Abepura lebih menarasikan kemah dengan tiang yang mengimajinasikan "tali-tali pasak", sedangkan gereja Surabaya menarasikan kap tenda. Menurut hemat saya, kemenonjolan tali pasak menggambarkan kesejenakan, sedangkan kap tenda menggambarkan muatan isinya.

Sejenak berhenti, mendirikan mezbah, dan mendirikan kemah atau pondok mengingatkan lintang liminitas. Berdasarkan Takenaka, tempat ibadah sebagai perjumpaan antara Allah dan umat, makrokosmos dan mikrokosmos, kekekalan dan waktu, merupakan ruang kudus yang simbolis dan sejenak berhenti (bnd. Kel. 3:5 Musa menanggalkan kasut di tanah kudus di gunung Sinai). ${ }^{101}$ Selebrasi liturgi adalah lintang liminitas supaya sejenak singgah untuk mengalami pemulihan.

Kapel Panti Werdha Hana di Kedaung-Pamulang, Tangerang Selatan, membuat sedikit manipulasi segitiga dengan profil gerbang. Menonjolkan ornamen profil garis segitiga sebagai eksterior pintu utama membuat kesan kemah pada bangunan ini.

98 Martin Tiranda, "GPIB Maranatha," GPIB Maranatha - Media Pariwisata Bangka Belitung, diakses 13 April 2021, https://explorebabel.com; Petuah dari Abah, "Gereja Jemaat Maranatha Yang Klasik Di Surabaya:Gereja Jemaat Maranatha Yang Klasik Di Surabaya," diakses 13 April 2021, petuahabah.blogspot. com.

99 Jayapura Space, "Warisan Arsitektur: Di Balik Arsitektur Gereja Kotaraja," diakses 15 April 2021, https://www.jayapura.space/warisan-arsitektur/158-di-balik-arsitektur-gereja-kotaraja.

100 Van de Ven, Ruang Dalam Arsitektur: Evolusi Dari Sebuah Gagasan Baru Dalam Teori Dan Sejarah Gerakan-Gerakan Modern, 72-73.

101 Takenaka, The Place Where God Dwells, 15-16, menganalogikan filosofi ma (antara), semisal: madori (pembagian ruang), mado (pintu antara), tokonoma (ruang peralihan) rumah Jepang . 


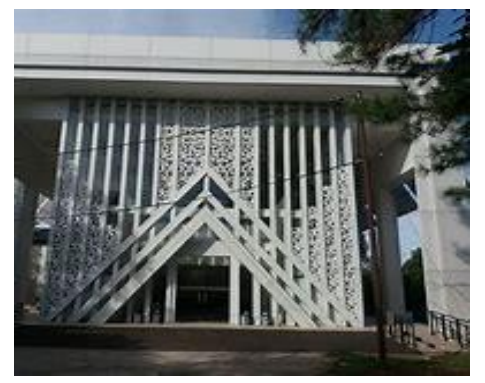

Gambar 8: tampak muka kapel PW Hana ${ }^{102}$

Manipulasi ini justru memperkuat kesan bahwa rumah lanjut usia, terutama kapelnya, merupakan lintang liminalitas pada masa peralihan (bnd. 2Kor. 5:1-5 kemah sebagai metafora universal, yakni kesementaraan hidup di dunia). Kesan universal ini adekuat dikenakan pada konteks multiagama.

Gagasan teologis sejenak berhenti berkonsekuensi berada dalam perjalanan. Sebagaimana arsitektur biduk, moving church tergambar dalam gereja segitiga kemah.

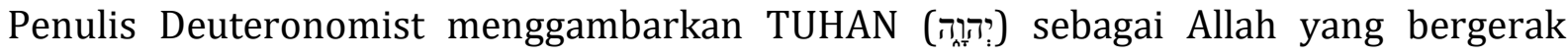
seturut umat-Nya (2Sam. 7:5-7 dan 1Taw. 17:4-6 “Aku tidak pernah diam ..., Aku mengembara ....”). Ruang Allah adalah kawasan nir-sekat namun berbatas, yakni jagat raya. Van de Ven menuliskan, berdasarkan ide ruang Isaac Newton (1642 - 1726/27), bahwa ketidak-tersekatan ruang merupakan bukti keberadaan TUHAN Yang Satu (Ul.


ubiquity) ${ }^{103}$ di tengah dan bersama umat.

TUHAN, dalam paparan Dozeman menurut tradisi Horeb Deuteronomist dari zaman pembuangan, adalah Tuhan yang bergerak (divine mobility atau mobile character of God). ${ }^{104}$ Berdasarkan Gerd Theissen, kebergerakan (Dominus ambulare = Tuhan berjalan) tergambar dalam gereja sangat awal. Wandering charismatics terejawantahkan dalam pelayanan Yesus, para penginjil, dan para rasul. ${ }^{105}$

\section{Gunung batu}

Kisah pengembaraan umat Israel di padang gurun berakhir pada proses memasuki tanah Kanaan. Setelah menjadi penduduk kota, Israel membuat kota berkubu, yakni tembok besar sekeliling dengan pintu kecil dan air (bnd. Mzm. 46:5). Roland de Vaux

102 Gereja Segi Tiga dan Panti Werda Hana, "Images of Panti Werda Hana," dan https://www.bing.com/images/search?q=panti+werda+hana\&qpvt=panti+werda+hana\&form=IQFRML\& first=1\&tsc=ImageBasicHover (diakses 12 April 2021).

103 Van de Ven, Ruang Dalam Arsitektur: Evolusi Dari Sebuah Gagasan Baru Dalam Teori Dan Sejarah Gerakan-Gerakan Modern, 38; Haryono, "Kehampaan (Nothingness): Sebuah Jalan Interspiritualitas", 6. Berdasarkan Meister Eckhart (1260-1328) menulis bahwa Tuhan "having no place, God is not 'where' but rather 'everywhere' and [we] live because [we] live" ; Dozeman, God on the Mountain: A Study of Redaction, Theology and Canon in Exodus 19-24, 72-73.

104 Dozeman, God on the Mountain: A Study of Redaction, Theology and Canon in Exodus 19-24, 7273.

105 Gerd Theissen, The First Followers of Jesus: A Sociological Analysis of the Earliest Christianity (London: SCM Press, 1978), 8. 
memaparkan bahwa model kota benteng ini merupakan adopsi benteng Kanaan, tidak termasuk Yerikho dan $\mathrm{Ai}$, pada zaman kerajaan. ${ }^{106}$ Gunung batu atau kota benteng (kubu) menggambarkan kekuatan, terutama bagi perlindungan penduduknya. Perlindungan penduduk terutama menyangkut kebutuhan makanan. Berbeda dengan happy ending cerita peperangan, Sivertsen menggambarkan bahwa Israel mengubah gaya hidup dari pengembara atau nomad menjadi penetap. Maka, akhir abad ketiga belas SM, Israel mulai membuka desa-desa baru dengan deforestasi (bnd. Yos. 17:1518). ${ }^{107}$ Jumlah populasi meningkat, sekalipun tingkat kematian juga meningkat, menghasilkan kota-kota besar yang perlu perlindungan.

Beberapa bangunan gereja menggambarkan gunung batu. Pada satu sisi, gunung batu menggambarkan kekuatan yang melindungi. Penduduk kota berkubu kuat dan besar itu adalah negeri berlimpah susu dan madu (Bil. 13:27-31). Pada lain sisi, kekuatan itu dapat menjadi penghalang. TUHAN merobohkan "benteng" Yerikho (Yos. 6) dan Ai (Yos. 8:1-29) karena menghalangi rencana-Nya atas Israel.

Namun, gunung batu Masa dan Meriba adalah harapan baru. Konflik Musa dan umat Israel mengisahkan gunung batu yang mengeluarkan air yang menyelamatkan umat Israel di padang gurun. Air yang keluar dari gunung batu itu menjadi mata air Masa dan Meriba (Kel. 17:6-7) yang memberi kehidupan.

Bangunan gereja berbentuk "batu" umumnya menyerupai atau berpola dasar batu karang: persegi, bersudut, lancip, menjulang, atau dinding rata di beberapa bagian lain, namun sangat sedikit terlihat "lubang" untuk pintu, jendela, dan ruang kosong. Selain GPIB Immanuel-Jakarta, GPIB Immanuel-Semarang (Gereja Blenduk), dibangun pada 1753, menggambarkan gereja berbentuk "batu". Blenduk (julukan masyarakat berarti kubah).108 Pola dasar bangunan gereja berbentuk "batu” adalah gunung batu



Gambar 9 (kiri): batu karang di teluk Halong, Vietnam; sumber: dokumentasi pribadi (2008);

Gambar 10 (kanan): Gereja Blenduk, Semarang; sumber: dokumentasi pribadi (2017)

106 De Vaux, Ancient Israel: Its Life and Institution, 233-234; Sivertsen, The Parting of the Sea: How Volcanoes, Earthquakes, and Plagues Shaped the Story of Exodus, 105-106; Lembaga Alkitab Indonesia, Alkitab Edisi Studi, 354, catatan bawah; de Vaux, 217, tentang Yerikho dan Ai yang telah menjadi


Lexicon, s.v. "שבר"; "שבו". Exodus, 144.

${ }^{107}$ Sivertsen, The Parting of the Sea: How Volcanoes, Earthquakes, and Plagues Shaped the Story of

108 Ilham Budhiman, "15 Gambar Gereja Dengan Arsitektur Indah Dan Unik Di Indonesia. Mana Favorit Kamu?: 4. Gereja Blenduk, Semarang," diakses 15 April 2021, https://www.99.co/blog/ indonesia/gambar-gereja-terindah-indonesia/. 


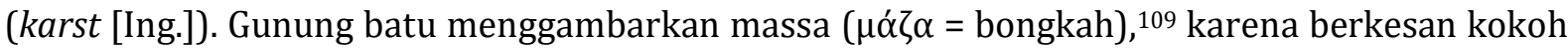
dan tahan terjangan angin dan badai. Bahkan gunung batu adalah penahan ombak, sehingga menjadi pelindung bagi kehidupan di sekitarnya. Beberapa kali, pemazmur memetaforakan Allah gunung batu (Mzm. 18:3, 32, 47; 19:15; 28:1; 42:10; 62:3, 7, 8; 73:26; 89:27; 92:16; 94:22; 95:1; 144:1) ${ }^{110}$ sebagai gambaran Allah pelindung.

\section{Guliran "akhir" perjalanan umat Israel}

Ujung akhir kitab Keluaran adalah perencanaan, persiapan, dan pendirian Kemah Suci pada tanggal 1 Nisan dan sekuensia ([Ing.] sequence = urutan) berjalan-jeda-kontinuitas umat Israel (Kel. 34 - 40). Janji (atau tujuan) di awal perjalanan akan tanah yang berlimpah dengan susu dan madu (Kel. 13:5) tak lagi menjadi tema narasi perjalanan di padang pasir pada tujuh pasal terakhir kitab Keluaran. Bangunan gereja, sebagaimana wujud Kemah Suci, menggambarkan sekuensia berjalan-jeda-kontinuitas-berjalan kembali atas umat.

Menurut Van de Ven berdasarkan Walter Gropius (awal abad kedua puluh), ruang dimulai dari konsep ruang imaterial atau ilusi (illusori space $=$ ) dan terukur (mathematical space). Gambar dua dimensional ini kemudian menjadi bangunan (material space $=$ ruang teraba), yakni ruang tiga dimensional. Bangunan, dengan rasa, ekspresi, atribut, dan intelek, menjadi ruang liturgi (artistic space atau spiritual space) yang utuh, berjiwa, dan hidup ${ }^{111}$ sebagai dimensi keempat, yakni muatannya yang melampaui ruang dan waktu.

Bangunan gereja adalah wujud konkret, baik sebagai tempat umat berkumpul maupun umat diutus. Sejak awal (Kel: 40:17 tanggal satu bulan pertama), tujuan berjalan "menuju" ibadah adalah bermisi di dunia. Van de Ven menyebut dimensi keempat ini: vision in motion. ${ }^{112}$ Maka, misi sebagai warta berkaryanya Allah di dunia sepantasnya tergagas dalam bangunan gereja menggambarkan misi Allah.

Misi atau pengutusan dalam selebrasi liturgi merupakan unsur terkecil. Namun bagi Constance Cherry, bagian terkecil ini mengingatkan jalinan relasi antara bubar dan segera jumpa kembali. ${ }^{113}$ Kisah kedua murid, setelah mengalami perjumpaan, mereka bergegas menuju Yerusalem untuk menceritakan pengalaman di Emaus. "Sementara

\footnotetext{
109 Van de Ven, Ruang Dalam Arsitektur: Evolusi Dari Sebuah Gagasan Baru Dalam Teori Dan Sejarah Gerakan-Gerakan Modern; " $\mu \alpha ́ \zeta \alpha ", \quad K a m u s$ Yunani-Indonesia Versi Daring, https://id.glosbe.com/el/id/.

110 Walker, "gunung batu" , Konkordansi Alkitab: Register Kata-Kata Dan Istilah Dari Alkitab Perjanjian Lama Dan Perjanjian Baru Dalam Terjemahan Baru.

111 Van de Ven, Ruang Dalam Arsitektur: Evolusi Dari Sebuah Gagasan Baru Dalam Teori Dan Sejarah Gerakan-Gerakan Modern, 270-272.

112 Ibid, 275.

113 Constance M Cherry, The Worship Architect: A Blueprint for Designing Culturally Relevant and Biblically Faithful Services (Grand Rapids: Baker Acedemic, 2010), 112.
} 
mereka bercakap-cakap, Yesus tiba-tiba berdiri di tengah-tengah" (Luk. 24:33-36). Tiga dari empat ayat tersebut berisi tentang cerita dan percakapan tentang kebangkitan dan penampakan Yesus. Penampakan Yesus adalah tanda kemahahadiran-Nya. Isi misi atau pengutusan umat di dunia adalah merenarasikan karya Allah di dalam Kristus.

Menurut Cherry, pengutusan adalah wahana umat menyalurkan berkat perjumpaannya dengan Allah. ${ }^{114}$ Musa bukan hanya diutus ke Mesir, tetapi juga memberi perintah Tuhan kepada Harun (Im. 9:22-23; Kel. 6:22-27). Pengalaman sukacita berjumpa Allah menginspirasi pelayanan sebagai pemenuhan perintah menjadi saksi. ${ }^{115}$ Pengutusan adalah mempersaksikan karya Tuhan di dalam aksi dan selebrasi.

\section{Kesimpulan}

Sebagai penutup, saya mengajukan tiga tawaran narasi, yaitu: Pertama, keberadaan bangunan gereja, terutama, adalah sebagai ruang liturgi. Maka bangunan gereja berisi narasi akan karya Allah menurut kesaksian Kitab Suci dalam peran gereja di dunia. Bangunan gereja tidak hanya berisi alkisah Allah mencipta, tetapi juga riwayat Allah berkarya dalam perjalanan bersama umat-Nya. Bagi yang menyadari kekuatan narasi akan bersikap sikap tremendum et fascinatum terhadap bangunan liturgi.

Kedua, tantangan bangunan yang mengagumkan adalah tuntutan estetika tidak melebihi narasi teologi atau fungsi ritual. Mangunwijaya melogikakan tuntutan keindahan dengan giat komersialisasi sebagai godaan zaman. Van de Ven, berdasarkan Imanuel Kant (1790), menyatakan salah satu kriteria keindahan adalah fungsi (necessary), selain bernilai universal, bebas nilai subjektif (uninterested), dan demi keindahan itu sendiri (purposeness without purpose). Inilah tantangan teologi arsitektur gereja modern, yaitu pilihan antara demi-keindahan bernilai jual atau fungsional namun bernarasi.

Ketiga, kebertubuhan, keselarasan, dan keharmonisan bangunan gereja dengan lingkungan, berdasarkan Frick, adalah panggilan teologi liturgi dewasa kini. Lingkungan yang dimaksud adalah demografi, yaitu: keberbagaian manusia, seni dan budaya, sejarah, lingkungan alam dan lokasi, merupakan keniscayaan berdirinya bangunan


= bersama, seukuran, pembatasan secara sama atau pemerataan) bukan hanya seimbang, tetapi juga "keselarasan (harmoni) antara unsur-unsur bagian dari suatu organisme dengan keseluruhan dari organisme itu." Maka, kebertubuhan, keselarasan, dan keharmonisan bangunan gereja merupakan ukuran ketika merencanakan pembangunan.

Jadi, menarasikan bangunan gereja adalah menghidupkan gereja dalam kontinuitas guliran. Jika umat pada masa kini merenarasikan bangunan gereja yang

114 Ibid, 113.

115 Ibid, 116. 
telah lama ada, maka umat menjadikan bangunan gereja bukan sekadar ornamen, monumen, tugu, instrumen, alat, atau perabot ibadah yang terbatas. Gereja adalah entitas hidup, bergerak, dan dinamis yang nir-batas.

\section{Referensi}

Adams, Edward. The Earliest Christian Meeting Places: Almost Exclusively Houses? Revised. London: Bloombury T\&T Clark, 2016.

Baker, D.L., and A.A. Sitompul. "Kamus Singkat Ibrani - Indonesia.” Jakarta: BPK Gunung Mulia, 2018.

Bell, Catherine. Ritual: Perspectives and Dimensions. New York: Oxford University Press, 1997.

Budhiman, Ilham. "15 Gambar Gereja Dengan Arsitektur Indah Dan Unik Di Indonesia. Mana Favorit Kamu?: 4. Gereja Blenduk, Semarang.” diakses 15 April 2021. https://www.99.co/blog/indonesia/gambar-gereja-terindah-indonesia/.

Cherry, Constance M. The Worship Architect: A Blueprint for Designing Culturally Relevant and Biblically Faithful Services. Grand Rapids: Baker Acedemic, 2010.

Davies, J.G. "The New Westminster Dictionary of Liturgy and Music." Philadelphia: SCM Press, 1986.

Dozeman, Thomas B. God on the Mountain: A Study of Redaction, Theology and Canon in Exodus 19-24. Atlanta: Scholars Press, 1989.

Eire, Carlos M N. War Against the Idols: The Reformation of Worship from Erasmus to Calvin. Cambridge: Cambridge University Press, 1986.

Eliade, Mircea. Images and Symbols: Studies in Religious Symbolism, Terj. Philip Mairet. Edited by Philip Mairet. Princeton: Princeton University Press, 1991.

Frick, Heinz. Arsitektur Dan Lingkungan. Yogyakarta: Kanisius, 1994.

Van Gennep, Arnold. The Rites of Passage. Edited by Gabrielle L. Caffee and Monika B.Vizedom. Chicago: The University of Chicago Press, 1992.

Hadiwijono, Harun. Konsepsi Tentang Manusia Dalam Kebatinan Jawa. Jakarta: Sinar Harapan, 1983.

Hariansah, Erik. "Punden Berundak, Arsitektur Asli Leluhur Nusantara." diakses 15 September 2021. https://attoriolong.com/2019/09/punden-berundakarsitektur-asli-leluhur-nusantara/.

Haryono, Stefanus Christian. "Kehampaan (Nothingness): Sebuah Jalan Interspiritualitas." Gema Teologika 6, no. 1 (2021): 1-16.

Hasuna. “Apa Itu Tawaf, Jenis-Jenis, Tata Cara, Dan Sunnah Pelaksanaannya.” diakses 15 September 2021. https://hasuna.co.id/apa-itu-tawaf/.

Heuken, Adolf. Gereja-Gereja Tua Di Jakarta. Jakarta: Cipta Loka Caraka, 2003.

Lahama, Theodorus Budiarjo. "Mengenal 'Palang Pintu', Tradisi Orang Betawi." diakses 21 April 2021. https://muda.kompas.id/baca/2018/07/04/mengenal-palang- 
pintu-tradisi-orang-betawi/.

Lembaga Alkitab Indonesia. Alkitab Edisi Studi. Jakarta: Lembaga Alkitab Indonesia, 2012.

Mangunwijaya, Y B. Wastu Citra: Pengantar Ke Ilmu Budaya Bentuk Arsitektur SendiSendi Filsafatnya Beserta Contoh-Contoh Praktis. Jakarta: Gramedia Pustaka Utama, 1995.

Maryanto, Ernest. Kamus Liturgi Sederhana. Yogyakarta: Kanisius, 2004.

Newman, Barclay M. “Greek-English Dictionary of the New Testament.” Stuttgart: Deutsche Biblegesellschaft, 2010.

Osburn, William. "A Hebrew and English Lexicon to the Old." Grand Rapids: Zondervan Publishing House, 1882.

Paeth, Scott R. Exodus Church and Civil Society: Public Theology and Social Theory in the Work of Jürgen Moltmann. Burlington: Ashgate Publishing Company, 2008.

Petuah dari Abah. "Gereja Jemaat Maranatha Yang Klasik Di Surabaya:Gereja Jemaat Maranatha Yang Klasik Di Surabaya." Accessed April 13, 2021. petuahabah.blogspot. com.

Rachman, Rasid. "Narasi Membangun Selebrasi: Gulir Ritual Kekristenan Awal.” Indonesian Journal of Theology 8, no. 2 (2020): 131-156. https://doi.org/10.46567/ijt.v8i2.179.

_- - "Tata Ruang Dalam Gereja Yang Secara Liturgis Menarasikan Karya Allah." Jurnal Theologia in Loco 3, no. 1 (2021): 43-61.

Raharjo, Timbul. "Kiblat Papat Lima Pancer," Laporan Penciptaan Seni Rupa Dalam Rangka Pameran Seni Visual: Memaknai Pusat, Pameran Foto, Sketsa, Sejarah, Dan Karya Seni Rupa Tentang Tugu Jogja Di Jogja Gallery Jl. Pekapalan 7 Alun-Alun Utara. Yogyakarta, 2012.

Roberts, Nicholas W. Building Type Basics for Places of Worship. Hoboken: John Wiley \& Son, Inc, 2004.

Setyawan, Bambang. "Begini Heningnya Pertapaan Bunda Pemersatu Gedono.” diakses 15 September 2021. https://www.kompasiana.com/bamset2014/57bc03e4ed9673c50f3818ae/begi ni-heningnya-pertapaan-bunda-pemersatu-gedono?page=2\&page_images $=1$.

Sivertsen, Barbara J. The Parting of the Sea: How Volcanoes, Earthquakes, and Plagues Shaped the Story of Exodus. Princeton dan Oxford: Princeton University Press, 2009.

Space, Jayapura. “Warisan Arsitektur: Di Balik Arsitektur Gereja Kotaraja.” diakses 15 April 2021. https://www.jayapura.space/warisan-arsitektur/158-di-balikarsitektur-gereja-kotaraja.

Sundari, Dewi. “Apa Itu Sedulur Papat Lima Pancer?” diakses 22 April 2021. https://www.dewisundari.com/.

———. "Pribahasa Jawa - Sri Gunung." diakses 21 April 2021. https://www.dewisundari.com/.

Susan J. White, and James F. White. Church Architecture: Building and Renovating for 
Christian Worship. Nashville: Abingdon Press, 1989.

Sweety. "Sekolah Minggu Ramah Anak Dengan Disabilitas: Studi Kasus Terhadap Praktik Sekolah Minggu Di Gereja Kristen Indonesia Gunung Sahari Jakarta." Sekolah Tinggi Filsafat Theologi Jakarta, 2019.

Takenaka, Masao. The Place Where God Dwells. Hongkong: CCA dan Asian Christian Art Association, 1995.

Theissen, Gerd. The First Followers of Jesus: A Sociological Analysis of the Earliest Christianity. London: SCM Press, 1978.

Tiranda, Martin. "GPIB Maranatha." GPIB Maranatha - Media Pariwisata Bangka Belitung. Accessed April 13, 2021. https://explorebabel.com.

De Vaux, Roland. Ancient Israel: Its Life and Institutions. Translated by John McHugh. New York: McGraw-Hill Book Company, Inc, 1961.

Veda School of Wisdom and Knowledge. "Pradakshina or Parikrama in Ancient Ritual." https://vedapathshala.com/2020/06/23/pradakshina-circumambulation/.

Van de Ven, Cornelis. Ruang Dalam Arsitektur: Evolusi Dari Sebuah Gagasan Baru Dalam Teori Dan Sejarah Gerakan-Gerakan Modern. Edited by Imam Djokomono and Prihminto Wio. Jakarta: Gramedia Pustaka Utama, 1991.

Walker, D F. “Konkordansi Alkitab: Register Kata-Kata Dan Istilah Dari Alkitab Perjanjian Lama Dan Perjanjian Baru Dalam Terjemahan Baru.” Jakarta: BPK Gunung Mulia, 2018.

White, L.Michael. The Social Origins of Christian Architecture, Volume II: Texts and Monuments for the Christian Domus Ecclesiae in Its Environment. Valley Forge: Trinity Press International, 1997.

Yong, Amos. The Bible, Disability, and the Church: A New Vision of the People of God. Grand Rapids: William B. Eerdmans Publisihing Company, 2011.

"Kamus Bahasa Sansekerta-Indonesia Versi Daring." http://www.sansekerta.org/kamus-sansekerta/,.

“Kamus Besar Bahasa Indonesia Versi Daring." https://www.kbbi.web.id/.

"Kamus Yunani-Indonesia Versi Daring." https://id.glosbe.com/el/id/. 